\title{
Organic and conventional farming differentially influenced soil respiration, physiology, growth and head quality of artichoke cultivars
}

\author{
Daniel Leskovar ${ }^{1 *}$, Yahia A. Othman ${ }^{1,2}$ \\ ${ }^{1}$ Texas A\&M AgriLife Research and Extension Center, Texas A \& M University, Uvalde, TX, USA, 78801. \\ ${ }^{2}$ Department of Horticulture and Crop Science, The University of Jordan, Amman, Jordan, 11942. \\ *Corresponding author.d-leskovar@tamu.edu
}

\begin{abstract}
Soil amendment using organic fertilizer has been used widely to dispose animal waste, reduce environmental pollution and improve soil and fruit quality. The objective of this two-year study was to assess the influence of organic and conventional systems on growth, marketable yield, head quality (chlorogenic acid and cynarin concentration) and soil chemical properties of globe artichoke (Cynara cardunculus). Cultivars used were Deserto, Lulu, Romolo, 11-018, 12-179, Green Globe Improved and Imperial Star. Fertilizers were applied to both conventional and organic soil through drip irrigation system. In both years, significant differences were found across cultivars and soil type. Although cultivar response to soil system treatments were inconsistent across the two growing seasons, the cv. Imperial Star had the lowest marketable yield and head quality. Artichoke grown in the conventional field had higher plant height and width, chlorophyll content index (SPAD), leaf area index (LAI), stomatal conductance $(g s)$, photosynthesis $(P n)$ and marketable yield. Conversely, artichoke head quality from the organic field was higher than conventional. Organic system increased chlorogenic acid by $31 \%$ and cynarin by $12 \%$ compared to the conventional system. In fact, after two years of soil amendment, organic fertilizer improved soil respiration- $\mathrm{CO}_{2}$ (soil health indicator) by 20 -fold compared to chemical fertilizer (conventional field). Overall, based on this two-year study we suggest organic farming as the best system to improve soil and head quality of globe artichoke, but it may not be the best option for farmers when yield is the primary target short-term.
\end{abstract}

Keywords: Cynara cardunculus, chlorogenic acid, cynarin, photosynthesis, stomatal conductance. 


\section{Introduction}

The disposal of livestock and poultry animal waste constitutes an environmental hazard and health issue. Soil amendment practices using organic fertilizers are preferred to mineral fertilizers because it disposes animal waste and reduces environmental pollution issues (Leogrande et al., 2013). The evaluation of results from 150 studies comparing the quality of conventionally and organically produced food revealed that inorganic cultivated vegetables had higher nitrate $\left(\mathrm{NO}_{3}^{-}\right)$content and pesticides residue levels than those grown under organic systems (Woese et al., 1997). A meta-data analysis of organic and conventional growing systems also found that organic crops contained higher vitamin $\mathrm{C}$, iron $(\mathrm{Fe})$, magnesium $\left(\mathrm{Mg}^{+2}\right)$, and phosphorus $(\mathrm{P})$ than conventional crops (Worthington, 2001). In fact, organic fertilizers have been reported as good sources of macro-nutrients (Gil et al., 2008). Additionally, the integration of optimum rates of inorganic and organic fertilizers can improve crop growth and productivity on a sustainable basis (Mahmood et al., 2017). In wheat (Triticum aestivum) grown under salinity stress $\left(\mathrm{EC}=7.84 \mathrm{dS} \cdot \mathrm{m}^{-1}\right)$, the integrated application of bio-fertilizer $\left(4 \mathrm{Kg} \cdot \mathrm{ha}^{-1}\right)$ with cattle manure $\left(10 \mathrm{t} \cdot \mathrm{ha}^{-1}\right)$ and inorganic nitrogen-fertilizers $\left(55 \mathrm{~kg} \cdot \mathrm{ha}^{-1} \mathrm{~N}\right)$ significantly improved growth, yield, and chemical constituents, and reduced heavy metal contents in shoots and seeds (Rady et al., 2016). Organic farming has been known to increase soil $\mathrm{N}$ supply capacity and soil $\mathrm{N}$ sequestration (Gong et al., 2011). After 12 years of continuous growing of 24 crops under different cultural systems, soils analyses showed that organic systems using compost and peat sources increased soil organic carbon content and altered microbial activities and microbial community structure compared with conventional system using inorganic chemical fertilizers) (Chang et al., 2014). More recently, Ciaccia et al. (2017) found that the combined use of plant-based organic manure (Vicia villosa) and rock-phosphate significantly improve yield and nutrient use efficiency in corn (Zea mays). They concluded that P-enriched compost is a viable option to sustain plant nutrient requirements, including N and P. In sugarcane (Saccharum officinarum), the combination of organic manure and chemical fertilizer increased soil fertility and leaf absorption of N, P and K compared to chemical fertilizer alone (Bokhtiar and Sakurai, 2005). It has been shown that organic fertilizers such as compost manure caused no heavy metal pollution into the soil and added acceptable levels of organic matter and nutrients to corn plants and soil (Gil et al., 2008). In a wheat-maize system, Yong et al. (2015) suggested that organic manure must be integrated with chemical $\mathrm{N}$ to sustain the productivity and promote $\mathrm{C}$ and $\mathrm{N}$ sequestration. However, organic farming is not an appropriate practice for growers when high yield and labor costs are the main concerns. In addition, it could add additional hidden management costs for growers due to the lack of consistent uniformity and stability of organic fertilizers (Gaskell and Smith, 2007).

Compared to conventional farming using inorganic chemical fertilization, an organic system can improve soil physical properties by significantly increased soil water retention capacity, soil water content and decreased soil bulk density and penetration resistance (Bassouny and Chen, 2016). For example, organic amendments of mine tailings based on processed waste rock sites in Canada using paper-mill sludge at a rate of $5.3 \mathrm{t} \cdot \mathrm{ha}^{-1}$ and woodchips at $5.6 \mathrm{t} \cdot \mathrm{ha}^{-1}$ led to improvements in plant cover of three species (Medicago sativa, Festuca rubra and Agropyron trachycaulum) and also survival, substrate aggregation and organic content (Young et al., 2015). Conversely, other amendments using chemical fertilizers never 
exceeded 50\% cover, nor it improved soil physical properties (Young et al., 2015). The application of organic fertilizer such as chicken manure or municipal sewage sludge increased marketable yield, ascorbic acid and phenols in kale (Brassica oleracea) and collard (Brassica oleracea) as compared to conventional soil amendments (Antonious et al., 2014). In addition, high soil organic matter resulted in higher soil biological activity as compared to soil with lower organic matter, and led to improve soil health and fruit quality, and suppressed plant diseases (Leskovar et al., 2016; Qiu et al., 2012). The application of bio-organic fertilizer based on a combination of manure composts and microorganisms was a useful and effective approach to suppress Fusarium wilt in cucumber (Cucumis sativus) plants (Qiu et al., 2012).

It has been claimed that organic agriculture could have more nutrients in the food products and lower negative impact to the environment (Santos et al., 2016). A comprehensive meta-analysis study based on 343 peer-reviewed publications concluded that organic crops grown across diverse regions and production seasons have higher antioxidant concentrations, lower cadmium concentrations and lower pesticide residues than conventional crops (Barański et al., 2014). However, an early meta-data analysis study did not find a strong evidence that organic foods are significantly more nutritious than conventional foods (Smith- Spangler et al., 2012). Noteworthy, that same study also concluded that organic foods had less pesticide residues and antibiotic-resistant bacteria (Smith- Spangler et al., 2012). Other studies indicate that tomato and spinach (Spinacia olearacea) organically-grown products had higher levels of ascorbic acid (vitamin C) and phenolic compounds with less nitrates than conventional-grown products (Mitchell et al., 2008). Similarly, the application of organic fertilizer increased total phenolics, flavonoids, ascorbic acid content and decreased nitrate in medicinal herb
(Labisia pumila) as compared to inorganic fertilizer (Ibrahim et al., 2013). On average, the concentration of polyphenolic compounds was consistently higher in organic crops, with an increase of phenolic acids (19\%), flavanones (69\%), flavonols (50\%) and anthocyanins (51\%) (Barański et al., 2014).

Globe artichoke (Cynara cardunculus) is a high valuable crop and rich source of antioxidant compounds such as dicaffeoylquinic acids, cynarin and phenolic acids, which are known to be beneficial for human health (Ciancolini et al., 2013; Moglia et al., 2008). Contemporary globe artichoke breeding program is aimed at developing new hybrid cultivars with enhanced vigor, quality and phytochemical content. However, how organic farming impact growth, head quality and soil health of field-grown globe artichoke is unknown, especially in newly developed genotypes. The objective of this study was to assess the influence of organic and conventional chemical fertilizers on artichoke growth, yield, head chlorogenic acid and cynarin concentration, and soil nutrient availability and respiration $\mathrm{CO}_{2}$.

\section{Materials and Methods}

\subsection{Site description and plant material}

The study was conducted over two years during October 2014 to June 2016, at the Texas A\&M AgriLife Research \& Extension Center in Uvalde (long. $29^{\circ}$ $13^{\prime \prime} \mathrm{N}$, lat. $99^{\circ} 45^{\prime \prime} \mathrm{W}$ ). Two sites were used, a conventional and certified organic field (with a previous history of 6 years under organic regimes), both having a clay soil type (hyperthermic Aridic Calciustolls of the Uvalde series). The organic field was certified organic by the Texas Department of Agriculture, Austin in 2009. For the conventional field, artichoke seeds of 7 cultivars were sown in polystyrene Speedling trays with 128 cells $(3.2 \times 3.2 \mathrm{~cm}$ square and 6.4 
cm deep) and placed in a germination chamber for 4 days in darkness inside an incubator chamber set at $20{ }^{\circ} \mathrm{C}$. Then, seedlings were transferred and grown in greenhouse conditions for 7 weeks prior to field planting. Mean minimum and maximum temperatures in the greenhouse were $22{ }^{\circ} \mathrm{C}$ and $27^{\circ} \mathrm{C}$, relative humidity were $30 \%$ to $60 \%$ and light intensity during the daytime was on average $960 \mu \mathrm{mol} \cdot \mathrm{s}^{-1} \cdot \mathrm{m}^{-2}$. For the organic field, artichoke transplants of the same 7 cultivars were grown in a certified organic nursery (Speedling Inc., Florida) for 8 weeks and transported to Uvalde prior to planting. Meteorological data of both fields, were obtained from the Texas A \& M AgriLife Research \& Extension Center weather station located nearby of both fields (Figure 1).

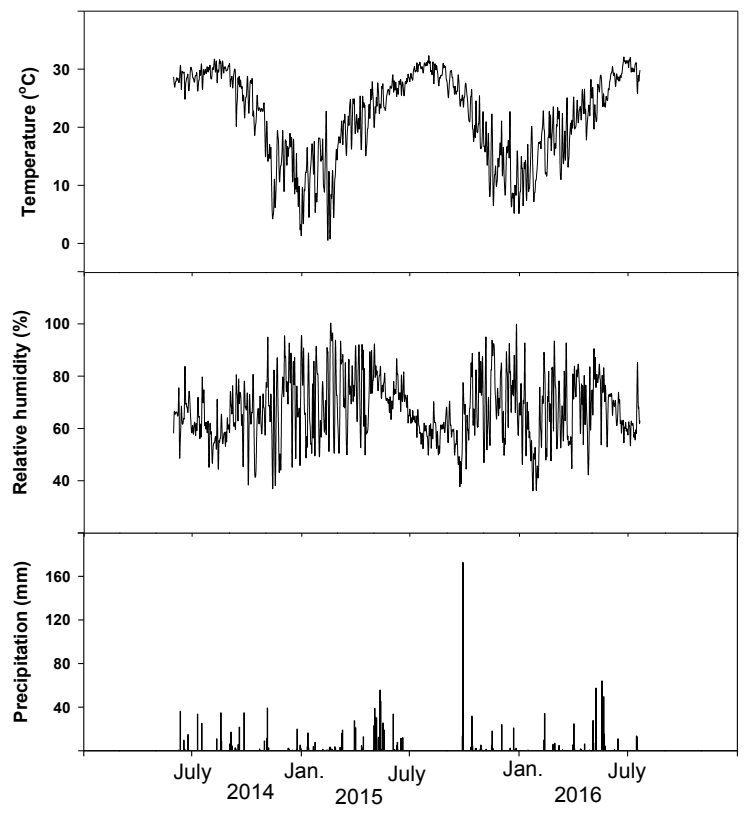

Figure 1. Average air temperature, relative humidity and precipitation of the study sites at Uvalde, Texas, during the experimental period (August 2014 - June 2016).

\subsection{Treatments and cultural practices}

Seven artichoke cultivars were used, Green Globe Improved and Imperial Star as open pollinated types with green-light purple color heads and the more contemporary hybrid cultivars Deserto, Lulu, Romolo,
12-179 and 11-018 (Big Heart Seed Co, Brawley, California) with purple color heads except for 11-018 that was green-light head. Mature 7-8 week-old transplants were established in the field in either organic or conventional beds with plants spaced in the center at $0.9 \mathrm{~m}$ within the row and $1.5 \mathrm{~m}$ apart between 
rows. Beds were laid out with a black plastic mulch to reduce weed pressure and soil evaporative water losses. In both sites, irrigation was established using a subsurface drip system placed in the middle of the bed at $15 \mathrm{~cm}$ depth. Drip tape used had emitters spaced every $30 \mathrm{~cm}$ with a flow rate of $0.91 \mathrm{l}^{\mathrm{h}} \mathrm{h}^{-1}$ at $0.07 \mathrm{MPa}$ (06SLF15636.2-12 Model; Netafim, Fresno, CA). Organic and inorganic fertilizers were injected through the irrigation system at an equivalent rate of $120 \mathrm{~N}, 100 \mathrm{P}$ and $100 \mathrm{~K} \mathrm{~kg}^{\cdot} \mathrm{ha}^{-1}$. Fertilizers were applied in 3 split doses across the growing seasons. The first dose $(20 \%$ of total fertilizers) was applied three weeks after transplanting, the second dose $(40 \%)$ at the 8 -leaf stage and the third (40\%) prior to the harvesting stage. The inorganic fertilizers $4 \mathrm{~N}-4.4 \mathrm{P}-8.3 \mathrm{~K}$ and $32 \mathrm{~N}-0 \mathrm{P}-0 \mathrm{~K}$ were used for the conventional site and Phytamin all purpose (3.7-2.7-3.7) was used in the organic field. Organic potash (0-0-4) and phosphate (0-200 ) were also incorporated into the top $20 \mathrm{~cm}$ soil surface in the organic site prior to planting to level the amount of $\mathrm{P}$ and $\mathrm{K}$ to that of the conventional field. Phytamin all purpose, organic potash and phosphate fertilizers were in the list of OMRI-approved (Organic Materials Review Institute). During the period between 2009 and 2014, the organic field was grown with winter wheat and legume crops. Commercial organic fertilizer (Phytamin all purpose) was inclusively added during the experimental period, 2014-2016.

Gibberellic acid $\left(\mathrm{GA}_{3}, 4 \%\right.$, CP Bio, Inc., Chino, CA) was sprayed twice at $20 \mathrm{mg} \cdot \mathrm{L}^{-1}$, the first at the four-leaf stage and the second $10 \mathrm{~d}$ after the first application to the conventional artichoke field (inorganic fertilizer). Additionally, esfenvalerate (Asana XL, 8.4\% by weight, DuPont, Wilmington, DE) at $70 \mathrm{ml} \cdot \mathrm{ha}^{-1}$ were applied to control cucumber beetle (Diabrotica undecimpunctata) during the vegetative stage. Due to the regulations of the
Texas State Department of Agriculture for certified organic fields, neither $\mathrm{GA}_{3}$ nor esfenvalerate were applied to the organic artichoke site.

\subsection{Plant morphology, physiology, yield and head phytochemical measurements}

Plant size (height and width), chlorophyll content index (SPAD), leaf area index (LAI), photosynthetic rate $(P n)$, stomatal conductance $(g s)$, and transpiration $(E)$ were measured at the vegetative and harvesting stage in both growing seasons. Morpho-physiological measurements were conducted between 1100 and 1300 HR. Chlorophyll content index was measured using a chlorophyll meter (SPAD-502 Plus, Minolta, Japan), and LAI with a ceptometer (LP-80, Decagon Devices, Pullman, WA). Gas exchange ( $P n, g s$ and $E$ ) measurements were determined from two fully expanded sunny-exposed leaves using a portable photosynthesis system (LI-6400XT; LI-COR, Lincoln, NE) following the procedures of Othman et al. (2014). Artichoke harvests were conducted between April and June 2015 and 2016 and marketable yield ( $\left(\mathrm{tha}^{-1}\right)$ was determined. A head was considered marketable when its diameter was higher than $7 \mathrm{~cm}$ and without tipburn and/or open bracts. During the harvesting stage in 2016, a representative head sample size (secondary heads, 8 heads per treatment) was taken and used to measure phytochemicals (chlorogenic acid and cynarin) concentration using a High Performance Liquid Chromatography system (HPLC, Waters Alliance 2695 Separation Module, Milford, MA 01757).

\subsection{Soil chemical properties analysis}

Soil samples (top $30 \mathrm{~cm}$ ) from plots where the cv. 12-179 was established in the organic and conventional sites were collected at the beginning (September 2014) and end of the study (July 2016). We 
selected this cultivar-location since an early study demonstrated the superior performance and adaptability of 12-179 for the semi-arid conditions of Texas (Leskovar and Othman, 2016). Soil respiration was measured using the Solvita Soil Respiration System. A $40 \mathrm{~g}$ of air-dried sieved $(2 \mathrm{~mm})$ soil was used. Soil $\mathrm{CO}_{2}-\mathrm{C}$ released was measured using a digitalcolor reader (Solvita-DCR, Woods End Laboratories, Inc, Mt. Vernon ME). For soil chemical analysis, samples were oven dried at $65^{\circ} \mathrm{C}$ for 16 hours. Electrical conductivity and $\mathrm{pH}$ was determined in a 1:2 (water:soil) extract. Soil $\mathrm{NO}_{3}-\mathrm{N}$ was measured using a spectrophotometer (Genesys 20, Thermo Scientific, Waltham, MA). Soil $\mathrm{P}, \mathrm{K}, \mathrm{Ca}^{+2}, \mathrm{Mg}^{+2}$, $\mathrm{Na}$ and $\mathrm{S}$ were measured by inductively coupled plasma mass spectrometry (ELAN ICP-MS, PerkinElmer Inc. Waltham, MA).

\subsection{Graphing and statistical analysis}

A randomized complete block design with two factors (seven cultivars and two soil sources) and four replications were used. Each plot consisted of 8 plants ( 32 plants total per cultivar and soil source). The analysis of variance (ANOVA) and the least significant deference test $(P=0.05)$ in SAS (Version 9.4 for Windows; SAS Institute, Cary, NC) was used to identify differences between cultivars, soil source (organic vs. conventional) and their interactions. Sigmaplot (Version 10.0 for Windows; Systat Software, San Jose, CA) was used to graph the results.

\section{Results}

\subsection{Morphology and physiology}

Plant height and width, chlorophyll content index (SPAD) and LAI were statistically different across cultivars and soil source during the experimental period (Table 1). In both years, cvs. 11-018, 12179, Deserto, Lulu, and Romolo had higher plant width and LAI than the open pollinated Green Globe Improved and Imperial Star. Plant height was similar for the open pollinated artichokes, while it was higher for cvs. 11-018, 12-179, Deserto, Lulu, and Romolo in 2016 compared to 2015. Open pollinated (Green Globe Improved and Imperial Star) cultivars had slightly lower plant width compared to hybrids cvs. 11-018, 12-179, Deserto, Lulu, ad Romolo in 2016 as compared to 2015. However, all cultivars had higher LAI in 2016 than in 2015 (Table 1). Artichoke plants grown in the conventional site (inorganic fertilizers) had consistently higher plant height and width, SPAD and LAI compared to those grown in the organic site in both years. There was a significant cultivar and soil type interaction for LAI in 2015 (Figure 2). The partitioning of that interaction indicated that six cultivars, '11-018' '12-179', 'Deserto', 'GGI', 'Lulu', and 'Romolo', had higher LAI than the open pollinated 'IS' in the conventional compared to the organic field Leaf gas exchange measurements ( $P n, g s$ and $E$ ) were overall similar among cultivars during the study period, 2015-2016, except for $E$ in 2016, which was higher for the hybrids and lower for the open pollinated cultivars (Table 2). However, across all cultivars leaf gas exchange was significantly different between the two soil sources. Specifically, $P n$ and $g s$ from the conventional soil were higher than those from the organic soil in 2015. Additionally, plants in the conventional soil had higher gs and $E$ than those grown in organic soil in 2016 (Table 2). After two years of soil amendment using organic (Phytamin all purpose) and synthetic (chemical) fertilizers, shoot total $\mathrm{N}$ and $\mathrm{NO}_{3}{ }^{-}$(shoot samples were taken from ' $12-179$ ') were significantly higher in conventional site (inorganic fertilizers) 
than in organic. For the conventional field the total $\mathrm{N}$ and $\mathrm{NO}_{3}$ - were $3.21 \%$ and $0.34 \%$, respectively.
Conversely, for the organic field, the total shoot $\mathrm{N}$ and $\mathrm{NO}_{3}$ - were $2.01 \%$ and $0.1 \%$, respectively.

Table 1. Plant height and width, chlorophyll content index (SPAD) and leaf area index (LAI) for artichoke cultivars grown in conventional or organic soils during 2015 and 2016. Measurements were conducted during the early harvesting stage.

\begin{tabular}{|c|c|c|c|c|c|c|}
\hline Year & & & $\begin{array}{l}\text { Height } \\
\mathrm{cm}\end{array}$ & $\begin{array}{l}\text { Width } \\
\mathrm{cm}\end{array}$ & SPAD & LAI \\
\hline \multirow[t]{12}{*}{2015} & \multirow[t]{7}{*}{ Cultivar (C) } & Deserto & $63.6 \mathrm{a}$ & $145 \mathrm{ab}$ & $55.6 \mathrm{bc}$ & $4.32 \mathrm{a}$ \\
\hline & & Lulu & $59.0 \mathrm{ab}$ & $148 \mathrm{a}$ & $59.0 \mathrm{a}$ & $4.04 \mathrm{a}$ \\
\hline & & Romolo & $63.9 \mathrm{a}$ & $146 \mathrm{ab}$ & $55.2 \mathrm{bc}$ & $4.24 \mathrm{a}$ \\
\hline & & $11-018$ & $54.8 \mathrm{~b}$ & $145 \mathrm{ab}$ & $56.3 \mathrm{bc}$ & $4.54 \mathrm{a}$ \\
\hline & & $12-179$ & $64.0 \mathrm{a}$ & $148 \mathrm{ab}$ & $54.8 \mathrm{c}$ & $4.43 \mathrm{a}$ \\
\hline & & Green Globe Improved & $63.8 \mathrm{a}$ & $138 \mathrm{bc}$ & $57.5 \mathrm{ab}$ & $3.36 \mathrm{~b}$ \\
\hline & & Imperial Star & $55.9 \mathrm{~b}$ & $133 \mathrm{c}$ & $55.3 \mathrm{bc}$ & $3.11 \mathrm{~b}$ \\
\hline & \multirow[t]{2}{*}{ Soil (S) } & Conventional & 67.9 & 153 & 59.2 & 4.81 \\
\hline & & Organic & 53.5 & 134 & 53.3 & 3.20 \\
\hline & \multirow[t]{3}{*}{$P$-value } & $\mathrm{C}$ & 0.03 & 0.02 & 0.02 & 0.0001 \\
\hline & & $\mathrm{S}$ & 0.0001 & 0.0001 & 0.0001 & 0.0001 \\
\hline & & $\mathrm{C} \times \mathrm{S}$ & 0.54 & 0.06 & 0.79 & 0.001 \\
\hline \multirow[t]{12}{*}{2016} & \multirow[t]{7}{*}{ Cultivar } & Deserto & $70.4 \mathrm{ab}$ & $152 \mathrm{a}$ & $54.4 \mathrm{ab}$ & $5.13 \mathrm{ab}$ \\
\hline & & Lulu & $71.4 \mathrm{a}$ & $157 \mathrm{a}$ & $55.8 \mathrm{a}$ & $5.59 \mathrm{a}$ \\
\hline & & Romolo & $74.4 \mathrm{a}$ & $157 \mathrm{a}$ & $48.7 \mathrm{~b}$ & $5.24 \mathrm{ab}$ \\
\hline & & 11-018 & $72.1 \mathrm{a}$ & $157 \mathrm{a}$ & $58.5 \mathrm{a}$ & $5.63 \mathrm{a}$ \\
\hline & & $12-179$ & $73.1 \mathrm{a}$ & $164 \mathrm{a}$ & $53.8 \mathrm{ab}$ & $5.76 \mathrm{a}$ \\
\hline & & Green Globe Improved & $63.0 \mathrm{bc}$ & $130 \mathrm{~b}$ & $54.4 \mathrm{ab}$ & $4.49 \mathrm{bc}$ \\
\hline & & Imperial Star & $55.8 \mathrm{c}$ & $124 \mathrm{~b}$ & $49.5 \mathrm{~b}$ & $3.87 \mathrm{c}$ \\
\hline & \multirow[t]{2}{*}{ Soil } & Conventional & 86.9 & 160 & 57.7 & 6.3 \\
\hline & & Organic & 50.3 & 138 & 49.5 & 3.9 \\
\hline & \multirow[t]{3}{*}{$P$-value } & $\mathrm{C}$ & 0.0001 & 0.0002 & 0.03 & 0.005 \\
\hline & & $\mathrm{S}$ & 0.0001 & 0.0001 & 0.0001 & 0.0001 \\
\hline & & $\mathrm{C} \times \mathrm{S}$ & 0.14 & 0.54 & 0.03 & 0.15 \\
\hline
\end{tabular}

Different letters within columns indicate a significant difference between cultivars $(P$-value $<0.05)$. Differences between conventional and organic soils are significant if $P \leq 0.05$. 


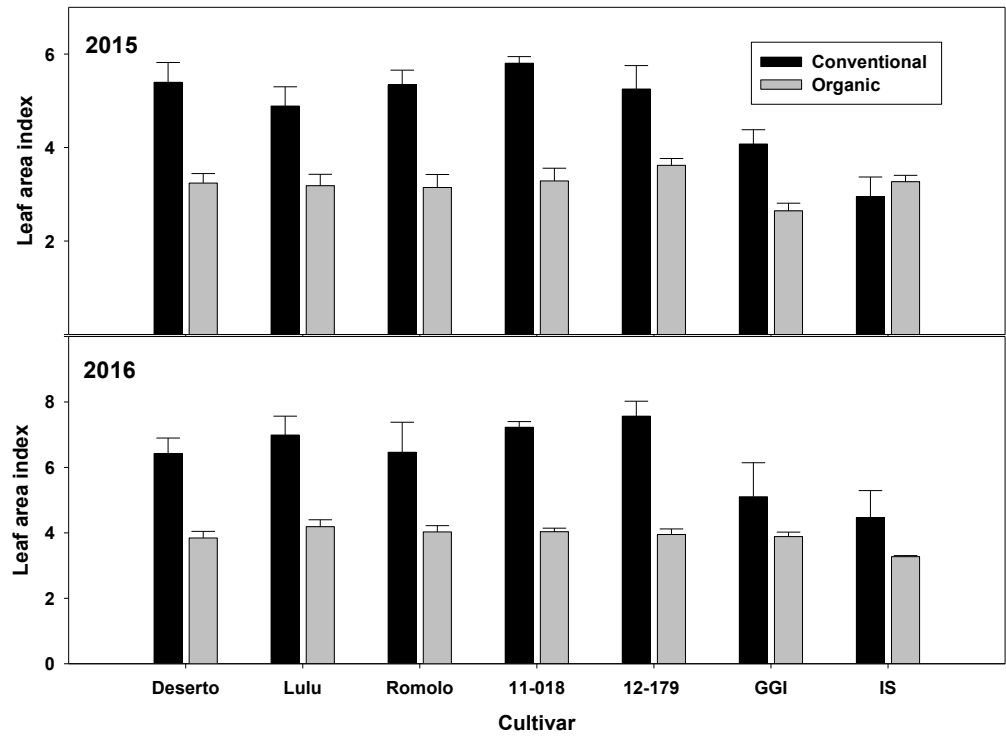

Figure 2. Leaf area index for artichoke cultivars grown in conventional or organic soil in 2015 and 2016.

\subsection{Yield and head quality}

Overall, marketable yield was lower in the 2015 growing season compared to 2016 in both soil types (organic and conventional) and across all cultivars (Figure 3 ). The open pollinated 'Imperial Star' had the lowest yield compared to other cultivars in conventional field in 2015 and in organic in 2016; while 'Green Globe Improved' had uniform yields in both seasons, being the highest in 2015 . Averaged across both years, the hybrids ' $12-179$ ' and ' $11-018$ ' had about $9 \%$ and $54 \%$ higher yields than the open pollinated 'Green Globe Improved' and 'Imperial Star', respectively. However, there were significant cultivar and soil treatment interactions for marketable yields in both years $(P=0.0001$ in 2015 and $P=0.04$ in 2016). The cultivar and soil treatment interactions revealed that, in both years, cultivars '12-179', '11-018' and Lulu from conventional soil had the highest yield compared to other cultivars from both organic and conventional soil (Figure 3). Marketable yield from conventional (inorganic fertilizer) was 9.7 and $6.4 \mathrm{t} \cdot \mathrm{ha}^{-1}$ higher than organic in 2015 and 2016, respectively. 
Table 2. Leaf-level photosynthesis $(P n)$, stomatal conductance $(g s)$ and transpiration $(E)$ of artichoke plants grown in conventional or organic soils. Measurements were conducted during the early harvesting stage.

\begin{tabular}{|c|c|c|c|c|c|}
\hline Year & & & $\begin{array}{c}P n \\
\left(\mu \mathrm{mol} \cdot \mathrm{m}^{-2} \cdot \mathrm{s}^{-1}\right) \\
\end{array}$ & $\begin{array}{c}g s \\
\left(\mathrm{~mol} \cdot \mathrm{m}^{-2} \cdot \mathrm{s}^{-1}\right) \\
\end{array}$ & $\begin{array}{c}E \\
\left(\mathrm{mmol} \cdot \mathrm{m}^{-2} \cdot \mathrm{s}^{-1}\right) \\
\end{array}$ \\
\hline \multirow[t]{12}{*}{2015} & Cultivar (C) & Deserto & 25.2 & 0.31 & 2.82 \\
\hline & & Lulu & 25.1 & 0.34 & 2.99 \\
\hline & & Romolo & 24.9 & 0.30 & 2.69 \\
\hline & & $11-018$ & 24.5 & 0.31 & 2.72 \\
\hline & & $12-179$ & 26.2 & 0.37 & 2.93 \\
\hline & & Green Globe Improved & 24.3 & 0.35 & 2.76 \\
\hline & & Imperial Star & 25.1 & 0.36 & 2.97 \\
\hline & Soil (S) & Conventional & 27.7 & 0.37 & 2.73 \\
\hline & & Organic & 22.4 & 0.29 & 2.95 \\
\hline & $P$-value & $\mathrm{C}$ & 0.54 & 0.15 & 0.87 \\
\hline & & $\mathrm{S}$ & 0.0001 & 0.0001 & 0.13 \\
\hline & & $\mathrm{C} \times \mathrm{S}$ & 0.15 & 0.17 & 0.75 \\
\hline \multirow[t]{12}{*}{2016} & Cultivar & Deserto & 17.7 & 0.35 & $4.68 \mathrm{ab}$ \\
\hline & & Lulu & 20.1 & 0.38 & $4.78 \mathrm{ab}$ \\
\hline & & Romolo & 21.5 & 0.38 & $4.80 \mathrm{ab}$ \\
\hline & & 11-018 & 20.0 & 0.39 & $4.97 \mathrm{a}$ \\
\hline & & $12-179$ & 20.4 & 0.38 & $4.64 \mathrm{ab}$ \\
\hline & & Green Globe Improved & 18.6 & 0.33 & $4.16 \mathrm{c}$ \\
\hline & & Imperial Star & 16.4 & 0.34 & $4.48 \mathrm{bc}$ \\
\hline & Soil (S) & Conventional & 18.8 & 0.46 & 5.91 \\
\hline & & Organic & 19.8 & 0.27 & 3.38 \\
\hline & $P$-value & $\mathrm{C}$ & 0.25 & 0.24 & 0.04 \\
\hline & & $\mathrm{S}$ & 0.37 & 0.0001 & 0.0001 \\
\hline & & $\mathrm{C} \times \mathrm{S}$ & 0.79 & 0.21 & 0.11 \\
\hline
\end{tabular}

Different letters within columns indicate a significant difference between treatments $(P$-value $<0.05)$.

In this study, the cvs. 11-018, Green Globe Improved (GGI) and Lulu from organic soil had higher chlorogenic acid and cynarin than conventional soil (Figure 4). However, although cvs. 12-179 and Imperial Star (IS) had similar chlorogenic acid head content in both soil type treatments, both cultivars had higher cynarin head content when grown in conventional soil (Figure 3). Overall, artichoke heads from the organic field had higher concentration of chlorogenic acid (31\%) and cynarin (12.4\%) than the conventional chemical fertilized treatment. 


\subsection{Soil chemical properties}

In this study, soil chemical analysis at the beginning of the experimental period (2014) revealed significant differences between organic and conventional fields in terms of soil $\mathrm{pH}, \mathrm{EC}$ and nutrient concentration $\left(\mathrm{NO}_{3}-\mathrm{N}, \mathrm{P}, \mathrm{Ca}^{+2}, \mathrm{Mg}^{+2}, \mathrm{~S}\right.$ and $\mathrm{Na}$ ) (Table 3). However, at that time no significant difference was noticed in soil respiration $\mathrm{CO}_{2}$ and $\mathrm{K}$. In addition, soil $\mathrm{pH}, \mathrm{EC}$, and $\mathrm{S}$ were similar in both fields at the end of the experiment (June 2016). After two years of soil amendment (2014-2016) using organic and conventional systems, organic soil had lower $\mathrm{NO}_{3}^{-}, \mathrm{P}, \mathrm{K}, \mathrm{Mg}^{+2}$ and higher $\mathrm{Ca}^{+2}$ than conventional soil. In 2016, organic soil had a higher level of $\mathrm{Na}$ than conventional (Table 3). In fact, $\mathrm{Na}$ increased 3 -fold in organic soil and decreased 2-fold in conventional soil during the experimental period (2014 to 2016). While soil respiration was similar in the conventional field (inorganic fertilizer) across the study period (2014-2016), a significant 15-fold increase in soil respiration $\mathrm{CO}_{2}$ was found in the organic field (Table 3) as compared to the baseline soil from 2014 .

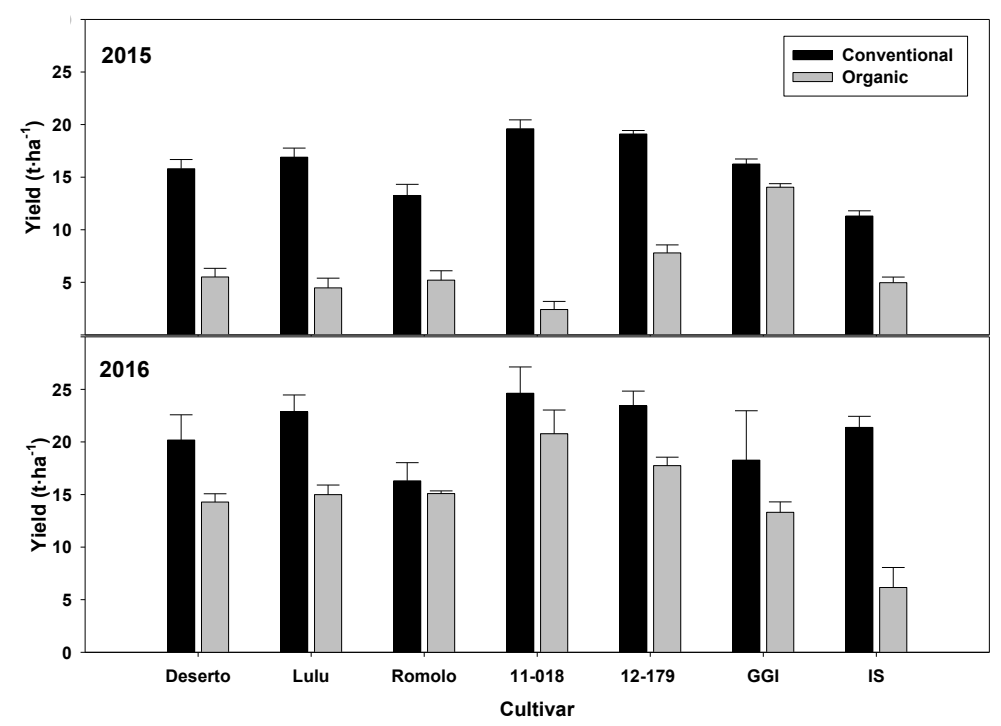

Figure 3. Marketable yield for artichoke cultivars grown in conventional or organic soil in 2015 and 2016 seasons. 


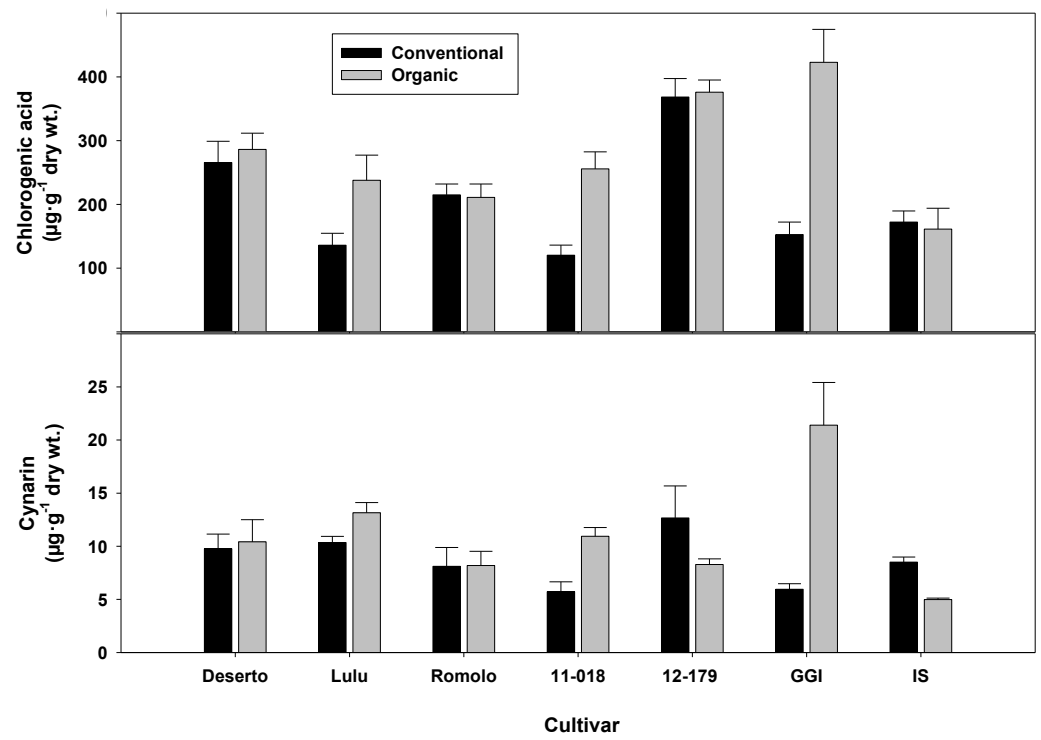

Figure 4. Chlorogenic acid and cynarin content for artichoke cultivars grown in conventional or organic soil in 2016.

\section{Discussion}

\subsection{Morphology and physiology}

Plant morphology (height and width) and physiology (SPAD and LAI) were statistically different across cultivars and soil source (Table 1). Artichoke plants grown in the conventional site had consistently higher plant size (height and width), SPAD and LAI compared to organic site in both years, except LAI of IS in 2015. Higher plant size and LAI in the conventional site could be attributed to the promotion effect of $\mathrm{GA}_{3}$ application, since it is known that exogenous $\mathrm{GA}_{3}$ enhances shoot growth and yield of globe artichoke by increasing the number of secondary heads (Paradiso et al., 2007). Additionally, higher shoot and SPAD values in conventional field could be attributed to the higher soil nutrient levels $\left(\mathrm{NO}_{3}, \mathrm{P}, \mathrm{Mg}^{+2}\right.$ and $\left.\mathrm{S}\right)$ at the beginning of growing season (Table 3). The challenge to synchronize nutrient release, specifically $\mathrm{N}$, from organic fertilizer sources with the plant growth demand has been discussed by Mikkelsen and Hartz (2008). In fact, these materials do not release considerable amount of $\mathrm{N}$ to a subsequent crop beyond 6 to 8 weeks after incorporation (Gaskell and Smith, 2007). Inadequate $\mathrm{N}$ supply during the growing season often results in low chlorophyll and growth rate, poor yield and inefficient water use (Mikkelsen and Hartz, 2008; Zhao et al., 2015).

Soil amendment systems (organic vs. conventional) can significantly impact plant growth and productivity (Antonious et al., 2014). Corn plants treated with organic fertilizer or microbial inoculant had higher $P n$ under soil water deficits than those treated with chemical fertilizers (Xu, 2001). However, although leaf gas exchange ( $P n, g s$ and $E$ ) did not differ significantly across cultivars during the study period, gas exchange from the conventional site were higher than those from the organic soil (i.e. $P n, g s$ in 2015 and $g s$ and $E$ in 2016) (Table 2). 
Table 3. Soil chemical properties for artichoke (cv. 12-179) grown in conventional and organic soil at the beginning (September, 2014) and the end (July, 2016) of the study period.

\begin{tabular}{|c|c|c|c|c|}
\hline \multirow[b]{2}{*}{ Year } & \multirow[b]{2}{*}{ Soil analysis } & \multicolumn{2}{|c|}{ Soil type } & \multirow[b]{2}{*}{$P$-value } \\
\hline & & Conventional & Organic & \\
\hline \multirow[t]{10}{*}{2014} & $\mathrm{pH}$ & 7.95 & 8.43 & 0.0004 \\
\hline & $\mathrm{EC}\left(\mu \mathrm{mho} \cdot \mathrm{cm}^{-1}\right)$ & 559 & 341 & 0.0002 \\
\hline & $\mathrm{NO}_{3}-\mathrm{N}\left(\mathrm{mg} \cdot \mathrm{l}^{-1}\right)$ & 28.5 & 5.7 & 0.0002 \\
\hline & $\mathrm{P}\left(\mathrm{mg} \cdot \mathrm{l}^{-1}\right)$ & 54.5 & 36.0 & $<0.0001$ \\
\hline & $\mathrm{K}\left(\mathrm{mg} \cdot \mathrm{l}^{-1}\right)$ & 810 & 838 & 0.443 \\
\hline & $\mathrm{Ca}^{+2}\left(\mathrm{mg} \cdot 1^{-1}\right)$ & 12939 & 15027 & 0.011 \\
\hline & $\operatorname{Mg}^{+2}\left(\mathrm{mg} \cdot \mathrm{l}^{-1}\right)$ & 333 & 293 & 0.006 \\
\hline & $\mathrm{S}\left(\mathrm{mg} \cdot \mathrm{l}^{-1}\right)$ & 29.0 & 15.7 & 0.0008 \\
\hline & $\mathrm{Na}\left(\mathrm{mg} \cdot \mathrm{l}^{-1}\right)$ & 49.5 & 20.0 & 0.0005 \\
\hline & $\mathrm{CO}_{2}-\mathrm{C}\left(\mathrm{mg} \cdot \mathrm{l}^{-1}\right)$ & 2.67 & 3.17 & 0.44 \\
\hline \multirow[t]{10}{*}{2016} & $\mathrm{pH}$ & 8.1 & 8.2 & 0.35 \\
\hline & $\mathrm{EC}\left(\mu \mathrm{mho} \cdot \mathrm{cm}^{-1}\right)$ & 359 & 391 & 0.51 \\
\hline & $\mathrm{NO}_{3}-\mathrm{N}\left(\mathrm{mg} \cdot \mathrm{l}^{-1}\right)$ & 22.0 & 4.8 & 0.01 \\
\hline & $\mathrm{P}\left(\mathrm{mg} \cdot \mathrm{l}^{-1}\right)$ & 61.5 & 34.0 & $<0.0001$ \\
\hline & $\mathrm{K}\left(\mathrm{mg} \cdot \mathrm{l}^{-1}\right)$ & 669 & 588 & 0.045 \\
\hline & $\mathrm{Ca}^{+2}\left(\mathrm{mg} \cdot 1^{-1}\right)$ & 10804 & 11199 & 0.06 \\
\hline & $\operatorname{Mg}^{+2}\left(\mathrm{mg} \cdot \mathrm{l}^{-1}\right)$ & 307 & 263 & 0.012 \\
\hline & $\mathrm{S}\left(\mathrm{mg} \cdot \mathrm{1}^{-1}\right)$ & 16.3 & 15.8 & 0.65 \\
\hline & $\mathrm{Na}\left(\mathrm{mg} \cdot \mathrm{l}^{-1}\right)$ & 28.3 & 64.3 & 0.0003 \\
\hline & $\mathrm{CO}_{2}-\mathrm{C}\left(\mathrm{mg} \cdot \mathrm{l}^{-1}\right)$ & 2.3 & 45.6 & 0.0001 \\
\hline
\end{tabular}

\subsection{Yield and head quality}

This study showed lower marketable yields in the 2015 growing season compared to 2016 in both soil types (organic and conventional). In addition, yield from the conventional site was higher than in the organic site in both growing seasons. It is well recognized that plant yield is associated with high photosynthetic values (Bondada and Oosterhuis, 2001). Interestingly, the percent increase in marketable yield from 2015 to 2016 was $31.3 \%$ in conventional field and $132 \%$ in organic field (Figure 3 ). One reason for this increase in the organic field might be attributed in part to the low soil microbial activity during the first growing season. Organic fertilizer treatments significantly improved soil respiration $\mathrm{CO}_{2}$ by 15 -fold, from 3.17 to $45.6 \mathrm{mg} \cdot \mathrm{l}^{-1}$, at the end of the study period (Table 3 ). In addition, mean maximum and minimum temperatures from Jan. - March 2015 was lower than in 2016 (Table 4). For example, in Jan. 2015, mean maximum temperatures was 16.2 ${ }^{\circ} \mathrm{C}$ and minimum was $3.2{ }^{\circ} \mathrm{C}$. In that month of 2016 , mean maximum and minimum temperatures were 17.3 and $4.0^{\circ} \mathrm{C}$, respectively. Lower temperatures in 2015 resulted in a lower yield compared to 2016 in both fields. 
Table 4. Monthly maximum and minimum air temperatures and total precipitation of the study sites during growing seasons (2015 - 2016).

\begin{tabular}{|c|c|c|c|c|c|c|}
\hline \multirow[t]{2}{*}{ Date } & \multicolumn{2}{|c|}{$\begin{array}{c}\text { Temperature } \\
\left(\text { Max. }{ }^{\circ} \mathrm{C}\right)\end{array}$} & \multicolumn{2}{|c|}{$\begin{array}{c}\text { Temperature } \\
\left(\text { Min. }{ }^{\circ} \mathrm{C}\right)\end{array}$} & \multicolumn{2}{|c|}{$\begin{array}{l}\text { Rainfall } \\
\text { (mm) }\end{array}$} \\
\hline & 2015 & 2016 & 2015 & 2016 & 2015 & 2016 \\
\hline Jan. & 16.2 & 17.3 & 3.2 & 4.0 & 50.3 & 24.9 \\
\hline Feb. & 17.8 & 22.9 & 6.3 & 7.4 & 15.5 & 44.0 \\
\hline March & 20.8 & 24.5 & 10.0 & 12.3 & 51.8 & 28.7 \\
\hline April & 26.1 & 27.4 & 16.5 & 15.5 & 69.3 & 34.8 \\
\hline May & 28.7 & 29.4 & 19.0 & 18.9 & 281.0 & 164.0 \\
\hline
\end{tabular}

Globe artichoke is a rich source of phenolic compounds which have been used for therapeutic effects (Ciancolini et al., 2013). In this study, artichoke heads from the organic site had higher concentration of chlorogenic acid and cynarin than the conventional site. Ibrahim et al. (2013) found that organic fertilizer significantly increased phenolic compounds, flavonoids, and ascorbic acid content in Labisia pumila as compared to chemical fertilizer. Phenolic profiles and antioxidant activities of Ziziphus jujube grown in organic soil were also reported to be higher than those grow by conventional fertilization (Wu et al., 2013).

\subsection{Soil chemical properties}

Soil amendment using organic system had resulted in reductions of soil $\mathrm{NO}_{3}^{-}, \mathrm{P}, \mathrm{K}^{-} \mathrm{Mg}^{+2}$ and increased $\mathrm{Ca}^{+2}$ compared to conventional. An early study comparing 21-year results from organic farming and conventional systems showed that nutrient inputs $(\mathrm{N}, \mathrm{P}, \mathrm{K})$ in the organic systems was 34 to $51 \%$ lower than in the conventional systems whereas $\mathrm{Ca}^{+2}$ and $\mathrm{Mg}^{+2}$ were higher (30 -50\%) (Mäder et al., 2002). After two years of soil amendments (20142016), Na in organic soil was markedly higher than conventional site. Li-Xian et al. (2007) found a potential risk for secondary soil salinization when high rates of chicken and pigeon manure are ap- plied. This is because external salt is normally added to animal diet to increase productivity and prevent mineral disorders (Diacono and Montemurro, 2015). Therefore, it is highly probable that organic fertilizer sources will significantly impact soil chemical properties as recently reported for animal-based (fish meal, blood meal, and chicken manure) or plant-based (alfalfa meal) fertilizers (Othman and Leskovar, 2018).

The remarkable benefit of organic farming is the strong and significant increase in microbial activity and diversity (Mäder et al., 2002). Soil respiration in the organic field was 20 -fold higher compared to conventional site (inorganic fertilizer) at the end of the experimental period (July, 2016). After three years of soil amendment using organic and inorganic fertilizers, organic compost increased soil $\mathrm{CO}_{2}$ respiration and enzyme activities compared to mineral fertilizers in vegetables grown in field conditions such as tomato (Solanum lycopersicum), snap bean (Phaseolus vulgaris) and lettuce (Lactuca sativa) (Iovieno et al., 2009). Organic farming was also shown to improve soil physical properties such as bulk density and penetration resistance, in addition to be a good source of macro-nutrients (Bassouny and Chen, 2016; Gil et al., 2008). After a long-term (18 years) study differing in chemical and organic fertilization programs, $\mathrm{N}$ storage of organic manure treated soil 
increased by $50 \%$ in the $20 \mathrm{~cm}$ topsoil over the chemical fertilizer NPK (Gong et al., 2011).

Soil microorganism and biotic parameters (e.g. abundance, diversity, food web structure, or community stability) are useful indicators of soil quality (Dorana and Zeiss, 2000). Soil microorganisms can potentially improve plant growth and fruit quality, decompose organic matter and suppress soil-borne diseases (Leskovar et al., 2016; Qiu et al., 2012). A recent study has shown a close association between soil microbial biomass $\mathrm{C}$ and the release of $\mathrm{CO}_{2}$ from the top soil (Franzluebbers, 2016). For example, the application of organic fertilization in an almond field (Prunus amygdalus) increased soil organic matter content and microbial activity whereas the inorganic fertilization resulted in higher release of $\mathrm{C}$ and $\mathrm{N}$ water soluble compounds (Macci et al., 2016).

\section{Conclusions}

Significant differences in plant morphology (plant height and width), physiology (SPAD, LAI and gas exchange), marketable yield, and head quality (chlorogenic acid and cynarin) were found in globe artichoke cultivars grown in conventional and organic soils. In the semi-arid to sub-humid conditions of southwest Texas, the standard open pollinated cv. Imperial Star and the hybrid cv. Romolo had the lowest marketable yield and head quality. In contrast cv. 12-179 had a consistent high yield and head quality across the study period. Artichoke plants grown in conventional fields had higher plant morphology, physiology, and marketable yield than in the organic field in both growing seasons. Conversely artichoke head from organic soil had higher chlorogenic acid, (considered a head quality indicator) and soil respiration $\mathrm{CO}_{2}$ (soil health indicator) than conventional soil. This 2-year study suggests that short-term conventional farming have a greater capacity to increase yield of artichoke compared to organic farming, while the latter may be a viable option long-term to improve soil and head quality.

\section{Acknowledgments}

This work is based upon work that was partially funded by the Texas Department of Agriculture, Specialty Crop Block Program. We also thank our staff Manuel Figueroa-Pagan, Juan Esquivel, Carrie Hensarling, Madhumita Joshi and Audra Elrod for their assistance in the laboratory and field. Appreciation is also extended to Rusty Jordan from Big Heart Seed Co (Brawley, California) for providing the new globe artichoke hybrid seeds.

\section{References}

Antonious, G., Turley, E., Snyder, J. 2014. Chicken manure enhanced yield and quality of field-grown kale and collard greens. J. Environ. Sci. Health B. 49: 299-304.

Barański, M., Srednicka-Tober, D., Volakakis, N., Seal C., Sanderson, R., Stewart, G., Benbrook, C., Biavati, B., Markellou, E., Giotis, C., Gromadzka-Ostrowska, J., Rembiałkowska, E., SkwarłoSońta, K., Tahvonen, R., Janovská, D., Niggli, U., Nicot, P., Leifert, C. 2014. Higher antioxidant and lower cadmium concentrations and lower incidence of pesticide residues in organically grown crops: a systematic literature review and metaanalyses. Br. J. Nutr. 112:794-811.

Bassouny, M., Chen, J. 2016. Effect of long-term organic and mineral fertilizer on physical properties in root zone of a clayey Ultisol. Arch. Agron. Soil Sci. 62: 819-828.

Bokhtiar, S., Sakurai, K. 2005. Effects of organic manure and chemical fertilizer on soil fertility and 
productivity of plant and ratoon crops of sugarcane. Arch. Agron. Soil Sci. 51: 325-334.

Bondada, B., Oosterhuis, D. 2001. Canopy photosynthesis, specific leaf weight, and yield components of cotton under varying nitrogen supply. J. Plant Nutr. 24: 469-477.

Ciancolini A, Alignan M, Pagnotta MA, Miquel J, Vilarem G, Crinò P. 2013. Morphological characterization, biomass and pharmaceutical compounds in Italian globe artichoke genotypes. Ind. Crops Prod. 49: 326-333.

Ciaccia, C. Ceglie, F., Tittarelli, F. Antichi, D., Carlesi, S., Testani E., Canali, S. 2017. Green manure and compost effects on N-P dynamics in Mediterranean organic stockless systems. J. Soil Sci. Plant Nutr. 17: 751-769.

Chang, E., Wang, C., Chen, C., Chung, R. 2014. Effects of long-term treatments of different organic fertilizers complemented with chemical $\mathrm{N}$ fertilizer on the chemical and biological properties of soils. Soil Sci, Plant Nutr. 60: 499-511.

Diacono, M., Montemurro, F. 2015. Review Effectiveness of Organic Wastes as Fertilizers and Amendments in Salt-Affected Soils. Agr. 5: 221230.

Dorana, J., Zeiss, M. 2000. Soil health and sustainability: managing the biotic component of soil quality. Appl. Soil Ecol. 15: 3-11.

Franzluebbers, A. 2016. Should soil testing services measure soil biological activity? Agr. Environ. Lett. 1: 1-5.

Gaskell, M., Smith, R. 2007. Nitrogen sources for organic vegetable crops. HortTechnol. 17: 431-441.

Gil, M., Carballo, M., Calvo, L. 2008. Fertilization of maize with compost from cattle manure supplemented with additional mineral nutrients. Waste Mgt. 28: 1432-1440.
Gong, W., Yan, X., Wang, J., Hu, T., Gong, Y. 2011. Long-term applications of chemical and organic fertilizers on plant-available nitrogen pools and nitrogen management index. Biol Fertil. Soils 47: 767-775.

Ibrahim, M., Jaafar, H., Karimi, E., Ghasemzadeh, A. 2013. Impact of organic and inorganic fertilizers application on the phytochemical and antioxidant activity of kacip fatimah (Labisia pumila Benth). Molecules 18: 10973-10988.

Iovieno, P., Morra, L., Leone, A., Pagano, L., Alfani, A. 2009. Effect of organic and mineral fertilizers on soil respiration and enzyme activities of two Mediterranean horticultural soils. Biol. Fertil. Soils 45: 555-561.

Leogrande, R., Lopedota, O., Fiore, A., Vitti, C., Ventrella, D., Montemurro, F. 2013. Previous crops and organic fertilizers in lettuce: effects on yields and soil properties. J. Plant Nutr. 36: 1945-1962.

Leskovar, D., Othman, Y. 2016. Morpho-physiological characteristics and yield of early and midseason globe artichoke. Acta Hort. 1147: 155-158.

Leskovar, D., Othman, Y., Dong, X. 2016. Strip tillage improves soil biological activity, fruit yield and sugar content of triploid watermelon. Soil Tillage Res.163: 266-273.

Li-Xian, Y., Guo-Liang, L., Shi-Hua, T., Gavin, S., Zhao-Huan, H. 2007. Salinity of animal manure and potential risk of secondary soil salinization through successive manure application. Sci. Total Environ. 383: 106-114.

Macci, C., Doni, S., Peruzzi, E., Mennone, C., Masciandaro, G. 2016. Biostimulation of soil microbial activity through organic fertilizer and almond tree association. Land Degrad. Develop. 27: 335-345.

Mäder, P., Fließbach, A., Dubois, D., Gunst, L., Fried, P., Niggli, U. 2002. Soil fertility and biodiversity in organic farming. Sci. 296: 1694-1697. 
Mahmood, F., Khan, I., Ashraf, U., Shahzad, T., Hussain, S., Shahid, M., Abid, M., Ullah, S. 2017. Effects of organic and inorganic manures on maize and their residual impact on soil physico-chemical properties. J. Soil Sci. Plant Nutr. 17: 22-32.

Mikkelsen, R., Hartz, T. 2008. Nitrogen sources for organic crop production. Better Crops. 92: 16-19.

Moglia, A., Lanteri, S., Comino, C., Acquadro, A., Beekwilder, J. Stress-induced biosynthesis of dicaffeoylquinic acids in globe artichoke. J. Agric. Food Chem. 2008, 56: 8641-8649.

Othman, Y., Leskovar, D. 2018. Organic soil amendments influence soil health, yield, and head phytochemicals of globe artichoke. Biol. Agr. Hort. DOI: $10.1080 / 01448765.2018 .1463292$

Othman, Y., VanLeeuwen, D., Heerema, R., St. Hilaire, R. 2014. Midday stem water potential values needed to maintain photosynthesis and gas exchange established for pecans. J. Amer. Soc. Hort. Sci. 139:537-546.

Paradiso, R., Cuocolo, B., De Pascale, S. 2007. Gibberellic acid and nitrogen rate affect yield and quality of artichoke. Acta Hortic. 730: 211-216.

Qiu, M., Zhang, R., Xue, C., Zhang, S., Li, S., Zhang, N., Shen, Q. 2012. Application of bio-organic fertilizer can control Fusarium wilt of cucumber plants by regulating microbial community of rhizosphere soil. Biol. Fertil. Soils 48: 807-816.

Rady, M., Mounzer, Q., Alarcón, J., Abdelhamid, M., Howladar, S. 2015. Growth, heavy metal status and yield of salt-stressed wheat (Triticum aestivum L.) plants as affected by the integrated application of bio-, organic and inorganic nitrogenfertilizers. J. Appl. Bot. Food Quality 89: 21-28.

Santos, F., Goufo, P., Santos, C., Botelho, D., Fonseca, J., Queirós, A., Costa, M., Trindade, H. 2016. Comparison of five agro-industrial waste-based composts as growing media for lettuce: Effect on yield, phenolic compounds and vitamin C. Food Chem. 209: 293-301.

Smith-Spangler, C., Brandeau, M., Hunter, G., Bavinger, C., Pearson, M., Eschbach, P., Sundaram, V., Liu, H., Schirmer, P., Stave, C., Olkin, I., Bravata, D. 2012. Are organic foods safer or healthier than conventional alternatives? Ann. Intern. Med. 57:348-66.

Woese, K., Lange, D., Boess, C., Bögl, K. 1997. A comparison of organically and conventionally grown foods-results of a review of the relevant literature. J. Sci. Food Agr. 74: 281-293.

Worthington, V., 2001. Nutritional quality of organic versus conventional fruits, vegetables, and grains. The J. Alternative and Complementary Med. 7: 161-173.

Wu, C., Gao, Q., Kjelgren, R., Guo, X., Wang, M. 2013. Yields, phenolic profiles and antioxidant activities of Ziziphus jujube Mill. in response to different fertilization treatments. Molecules. 18: 12029-12040.

Xu, H. 2001. Effects of a microbial inoculant, organic fertilizer and chemical fertilizer on water stress resistance of sweet corn. J. Crop Prod., 3: 223-233.

Yong, T., Liu, X., Yang, F., Song, C., Wang, X., Liu, W., Su, B., Zhou, L., Yang, W. 2015. Characteristics of nitrogen uptake, use and transfer in a wheat-maize soybean relay intercropping system. Plant Prod. Sci. 18: 388-397.

Young, I., Renault, S., Markham, J. 2015. Low levels organic amendments improve fertility and plant cover on non-acid generating gold mine tailings. Ecol. Eng. 74: 250-257.

Zhao, W., Yang, X., Yu, H., Jiang, W., Sun, N., Liu, X., 2015. RNA-Seq-based transcriptome profiling of early nitrogen deficiency response in cucumber seedlings provides new insight into the putative nitrogen regulatory network. Plant Cell. Physiol. 56, 457-467. 